Klinik Araştırma/Clinical Research

\title{
Kene ısırması sonucu acil servise başvuran hastaların epidemiyolojik açıdan değerlendirilmesi
}

Epidemiologic evaluation of patients admitted to the emergency department due to tick bites

Türker Yardan*a ${ }^{A h m e t} \operatorname{Baydın}^{a}, \operatorname{Nurşah~Başol}^{a}$, Latif Duran $^{a}$, Mustafa Sünbül $^{b}$

a Ondokuz Mayıs Üniversitesi, Tip Fakültesi, Acil Tıp Anabilim Dalı, Samsun

${ }^{b}$ Ondokuz Mayıs Üniversitesi, Tip Fakültesi, Klinik Mikrobiyoloji ve İnfeksiyon Hastalıkları Anabilim Dalı, Samsun

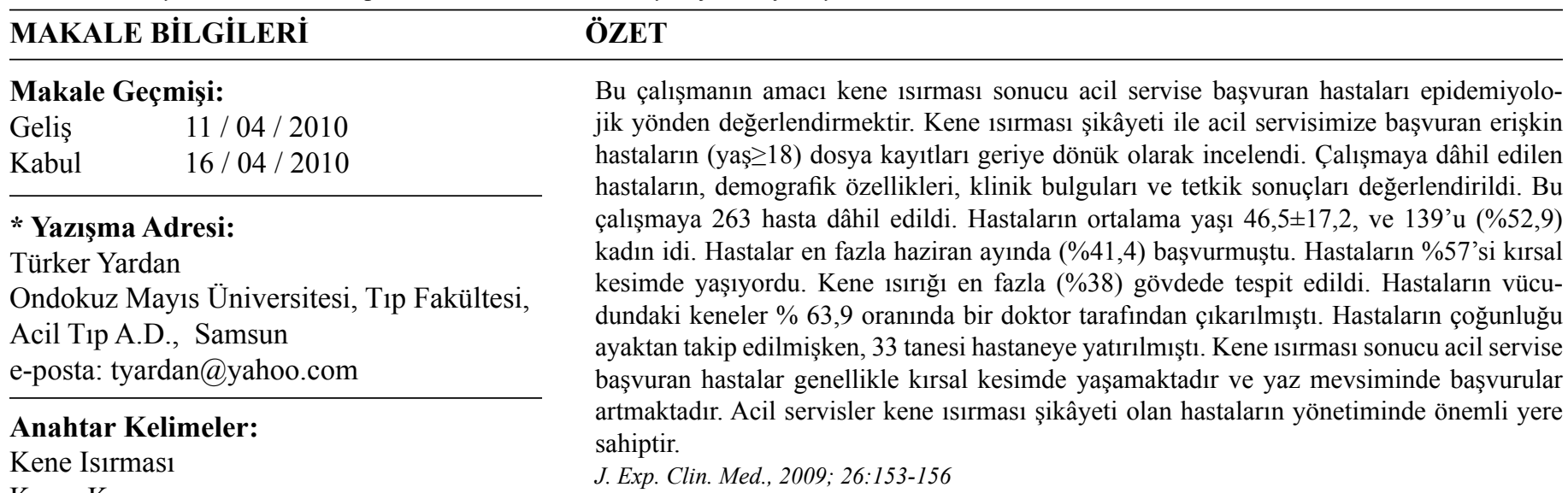

Kırım Kongo

Kanamalı Ateş

Acil Servis

Epidemiyoloji

Viral İnfeksiyon

Key Words :

Tick Bite

Crimean-Congo

Hemorrhagic Fever

Emergency Department

Epidemiology

Viral Infection

\begin{abstract}
This study aimed to evaluate the epidemiologic features of patients who admitted to Emergency Department (ED) due to the tick bite. This study was designed retrospectively by examining medical records of the patients $($ age $\geq 18)$ who were admitted to our ED with complaints of tick bite. Demographic and clinical features and laboratory findings of the patients were assessed. A total of 263 patients was included for the study. The mean age of the patients was $46,5 \pm 17,2$ and 139 of them wen female $52.9 \%$. Most of the patients were admitted to the ED in June. 150 of patients (\%57) were living in rural areas. The tick bites were mostly found in trunk part of the patients $(38 \%)$. The ticks, on the body surface of the patients, were mostly removed by doctors $(63.9 \%)$. While most of the patients were discharged from the ED with suggestions for turning back to control, 33 of them were hospitalized. Patients with tick bites are commonly living in rural areas and admission rate to the ED is being increased in the summer. The EDs have important role in the management of patients with complaints of tick bite.

J. Exp. Clin. Med., 2009; 26:153-156

(C) 2009 OMÜ Tüm Hakları Saklıdır.
\end{abstract}

\section{Giriş}

Ülkemizde, son yıllarda kene isırığına bağlı olarak hastanelerin acil servislerine başvuran olguların sayısı giderek artmaktadır. Keneler insan ve hayvan kanından beslenen artropodlar olup tüm dünyada tropik ve subtropik kuşakta gözlenirler. Ülkemizde halk arasında sakırga, yavs1, kerni gibi isimlerle de alırlar (Sümer, 2010). Kenelerin taşıdıkları virüsü insanlara bulaştırması Kırım Kongo Kanamalı Ateşi (KKKA) hastalığına sebep olabilmektedir (Acar, 2006; Akyazı ve Ecevit, 2006). Bu hastalık Asya'da,
Ortadoğu'da, Afrika'da ve Doğu Avrupa'da sik görülürken, ülkemizde de 2000 y1lından itibaren özellikle Tokat, Amasya, Çorum, Yozgat, Sivas, Samsun, Gümüşhane ve Ordu illerinde giderek artan sıklıkta görülmeye başlanmıştır (Bozkurt ve ark., 2005 ).

KKKA hastalı̆ğ, insanlarda genellikle ateş ve kanamalarla seyreden ağır bir klinik tabloya yol açarken, bazen ölüme de neden olmaktadır. Ülkemizde KKKA'ne bağlı ölen hasta sayısının son yıllarda artması kene 1sırıklarının önemini arttırmıştır. Hastalığın inkübasyon süresi 
virüsün alınma yoluna bağlıdır. Kene 1sırığını izleyen infeksiyonda inkübasyon süresi genellikle 1-3 gün olmak üzere, en fazla 9 gündür. Hastalık infekte kan ya da doku ile temas sonrasında gelişirse inkübasyon süresi 5-6 gün en fazla 13 gün olabilmektedir (Çevik, 2004). Bu hastalık ateş, vücutta yaygın ağrı, bulantı ve kusma, karın ağrısı, ishal, kanamalar ve ekimozlar şeklinde başlayabilir. Hematemez, melena, epistaksis, hematüri, dişeti kanaması vajinal kanama ve iç organ kanamaları da gelişebilir. Batın içi kanamalar karın ağrısı ve akut karın tablosu şeklinde ortaya çıkabilir. Ayrıca laboratuar anormallikleri de (yüksek transaminaz değerleri, trombositopeni, lökopeni ve/ veya lökositoz, anemi) karşımıza çıkabilir (Swanopel ve ark., 1989; Çevik, 2004). Ölümler genellikle klinik bulguların ikinci haftasında görülür. Hafif ve orta derecede klinik seyir gösterenler yaklaşı 9-10 günde iyileşir (Çevik, 2004). KKKA'ne bağlı ölüm oranı \%10-50'dir (Ergönül, 2008; Onguru ve ark., 2008).

Biz bu çalışmada kene 1sırığ sonucu acil servisimize başvuran hastaların demografik özelliklerinin belirlenmesi, klinik bulgularının irdelenmesi ve tetkik sonuçlarının değerlendirilmesi amaçladık.

\section{Gereç ve Yöntem}

Ondokuz Mayıs Üniversitesi Tıp Fakültesi erişkin acil servisine Nisan 2007-Eylül 2008 tarihleri arasında kene 1sırığı yakınması ile başvurmuş olan 263 hastanın (yaş $\geq 18$ ) dosya bilgileri etik kurul onayı alındıktan sonra, geriye dönük olarak incelendi. Hastaların dosyalarından demografik özellikleri (yaşı, cinsiyeti, mesleği), acil servise başvuru ayı, yaşadığı yer, keneyi kimin çıkardığı, acil servise başvuru yakınması, kenenin 1sırdığı bölge, laboratuar bulguları, hastaneye yatış ve son durumları kaydedildi. Kene 1sırması nedeniyle acil servisimize başvuran olguların tümünde tam bir fizik muayene yapılmış ve tüm vücut bölgeleri inspeksiyon ile değerlendirilmişti. Vücutlarında kene ile acil servise gelen hastalarda keneler uygun bir şekilde çıkartıldı. Hastaların dosyasından elde edilen veriler SPSS 15.0 (Statistical Package for Social Science) bilgisayar programına yüklendi ve değerlendirildi. Veriler sıklık ve ortalama \pm standart sapma olarak verildi.

\section{Bulgular}

Çalışmaya alınan 263 hastanın 139'u kadın $(\% 52,9), 124$ 'ü erkek $(\% 47,1)$ hastalardan oluşmaktaydı. Hastaların yaşları 18 ile 89 yıl arasında ve yaş ortalaması $46,5 \pm 17,2$ yıl idi. Hastaların başvuru aylarını incelediğimizde; 3'nün $(\% 1,1)$ Nisanda, 47 'sinin $(\% 17,9)$ Mayısta, 109 'nun $(\% 41,4)$ Haziranda, 59'nun $(\% 22,4)$ Temmuzda, 34 'nün $(\% 12,9)$ Ağustosta ve 11 'nin $(\% 4,2)$ ise Eylülde başvurduğunu tespit ettik.

Hastaların yaşadıkları yere baktığımızda 150 'sinin (\%57) köy ve kasabada yaşadığını, 113'nün ise (\%43) şehirde yaşadığını saptadık. Hastaların mesleklerini incelediğimizde; 53'nün $(\% 20,2)$ tarım işçisi, 68 'nin $(\% 25,9)$ hayvancılıkla uğraştığını, 10'nun $(\% 3,8)$ sağlık çalışanı, 12 'nin $(\% 4,6)$ öğrenci, 6'nın (\%2,3) asker, 43'nün (\%16,3) ev hanımı olduğunu ve 71'nin (\%27) meslek kaydının dosyada bulunmadığını tespit ettik.

Keneyi kimin çıkardığını incelediğimizde; \%30.4'nü (n=80) hastanın kendisi, \%5,7'sini $(n=15)$ hastanın yakını, \%25,1 'ni (n=66) başka bir sağlık kuruluşunda doktor ve \%38,8'ni $(n=102)$ ise acil servisimizde görevli doktor tarafından çıkarıldığını tespit ettik.

Hastaların başvuru esnasında temel şikâyet olan kene 1sırmasının yanı sira görülen diğer semptom ve bulgular Tablo 1'de verilmiştir. Kenelerin hastaları 1sırdığ 1 bölgeleri incelediğimizde en s1k \%38 (n=100) ile gövde olduğunu ve bunu azalan sıklıkta sirasiyla \%28,1 $(\mathrm{n}=74)$ kol, \%19,8 $(\mathrm{n}=52)$ bacak, \%8,7 $(\mathrm{n}=23)$ baş-boyun ve $\% 5,3$ $(n=14)$ ile genital bölgenin izlediğini saptadık.

Tablo 1. Kene 1sırıklı olgularda görülen semptom ve bulgular

\begin{tabular}{|lcc|}
\hline Semptom ve Bulgular & Hasta sayısı & Yüzde oranı \\
\hline Ateş & 35 & $\% 13,3$ \\
\hline Halsizlik & 32 & $\% 12,2$ \\
\hline Bulantı-kusma & 25 & $\% 9,5$ \\
\hline Miyalji & 24 & $\% 9,1$ \\
\hline İshal & 9 & $\% 3,4$ \\
\hline Ekimoz & 7 & $\% 2,7$ \\
\hline Boğaz ağrısı & 4 & $\% 1,5$ \\
\hline Sarılık & 1 & $\% 0,4$ \\
\hline
\end{tabular}

Yap1lan laboratuar incelemelerinde; hemoglobin değerleri 5,20-19 arasında değişmekte olup ortalama hemoglobin düzeyi $13,2 \pm 2,1 \mathrm{gr} / \mathrm{dl}$, beyaz küre sayıs1 535-19.000 arasında değişmekte olup ortalama beyaz küre say1s1 7,14 $\pm 2,5 \mathrm{bin} / \mathrm{uL}$, trombosit say1s1 14.100-557.000 bin/uL arasında değişmekte olup ortalama trombosit say1s1 225,8 $\pm 81,5 \mathrm{bin} / \mathrm{uL}$, aspartat aminotransferaz (AST) 10-2546 arasında değişmekte olup ortalama AST düzeyi $48,4 \pm 176,1 \mathrm{U} / \mathrm{L}$, alanin aminotransferaz (ALT) 7-1883 arasında değişmekte olup ortalama ALT düzeyi 44,4 4138,7 $\mathrm{U} / \mathrm{L}$, ve INR düzeyi 0,79 ile 1,64 arasında değişmekte olup ortalama INR düzeyi $0,97 \pm 0,12$ olarak bulundu. Tüm başvurulardan 33'nün $(\% 12,5)$ acil servisten infeksiyon hastalıkları kliniğgine yatırıldığını, 230 'nun $(\% 87,5)$ ise kontrole gelmek üzere acil servisten taburcu edildiğini tespit edildi. KKKA tanısı için 30 hastaya $(\% 11,5)$ ileri tetkik yapıldı $\mathrm{n}$, bu hastaların 8 'inde hastalığın doğrulandığını ve hastalarımızdan 2'sinin öldüğünü saptadık.

\section{Tartışma}

Kene 1sırığı olgularına her yaşta ve her iki cinsiyette rastlanmaktadır. (Arıkan ve ark., 2009) 253 çocuk üzerinde yaptıkları bir çalışmada; olguların \%66'nın erkek, \%34'nün kız cinsiyette olduğunu ve bu olguların yaş ortalamasının $6,6 \pm 3,3$ yıl olduğunu rapor etmişlerdir. Hastanemizde çocuk hastalar Çocuk Acil Servisi tarafindan takip edildiği için, çalışmamızda çocuk yaş grubundaki hastalar değerlendirilmemiştir. Ancak literatürde, erişkin yaş grubunda kene 1sırıklarının erkek cinsiyette daha fazla gö- 
rüldüğü bildirilmiştir (Al ve ark., 2008; Edlow ve McGillicuddy, 2008; Onguru ve ark., 2008; Kandiş ve ark., 2010). Çalışmamızda biz, kene 1sırıklarının kadın cinsiyette daha fazla görüldüğünü saptadık. Biz bu farklılı̆̆ın bölgemizdeki kadınların kırsal kesimde, tarım ve hayvancılıkta aktif rol almaları ile ilişkili olabileceğini düşünmekteyiz.

İnsan ve hayvanlardan kan emerek beslen canlılar olan keneler dünyanın her bölgesinde görülebilmektedir. Keneler genellikle yaşamaları için iklim yapısının uygun olduğu bölgelerde ve hayvancılığın yaygın olarak yapıldığ yerlerde daha sik 1sırıklara neden olmaktadır. (Yilmaz ve ark., 2008) ülkemizde 2008 yılında toplam kene 1sırı̆̆1 olgusunun 688 olduğunu, 1sırıkların Mart ayında başladığını fakat en fazla yaz aylarında görüldügünü bildirmişlerdir. Kene isırığ 1 ile acil servislere başvuran olguların başvurdukları ayların incelendiği farklı çalışmalarda kene 1sırıklarının Mayıs ile Ağustos ayları arasında sık görüldügü bildirilmiştir (Al ve ark., 2008; Arıkan ve ark., 2009; Kandiş ve ark., 2010; Sümer, 2010). Çalışmamızda, kene 1sırığ ziran ayında olduğunu ve bunun literatürle uyumlu olduğunu saptadık.

Kene 1sırığı ile hastaneye başvuran olguların çoğunu köy ve kasaba gibi kırsal kesimde yaşayan insanların oluşturduğu yapılan farklı çalışmalarda belirtilmiştir. (Taşkesen ve ark., 2008) \%53'nün, (Kandiş ve ark., 2010) \%64,4'nün, (Al ve ark., 2008) \%82'nin, (Sümer, 2010) ise $\% 53,5$ 'nin kırsal kesimden geldiğini bildirmişlerdir. Biz çalışmamızda, kırsaldan kesimden kene ısırığı ile acil servisimize başvuran hastalarımızın sayısının önceki çalışmalar ile uyumlu olduğunu saptadık.

Kene 1sırığ 1 için risk altında bulunan kişilerin veterinerler, sağl1k personeli, hayvancıllk yapanlar, mezbahane çalışanları, kasaplar, tarım işçileri ve askerler olduğu belirtilmektedir (Al ve ark., 2008; Y1lmaz ve ark., 2008). Çalışmamızda hastaların mesleklerini incelediğimizde en çok \%25,9 ile hayvancilık ve \%20,2 ile çiftçilik olduğunu tespit ettik. Daha az oranda öğrencilerde ve ev hanımlarında da kene 1sırığı görülmesinin sebebinin, ilkbahar ve yaz aylarında park, bahçe ve plajlarda daha fazla zaman geçirilmesinden kaynaklandığını düşünüyoruz.

Kenelerin mümkün olan en kısa sürede uzmanlar tarafından hastanın vücudundan uzaklaştırılması gerektiği belirtilmektedir. Kenelerin vücuttan uzaklaştırılması işlemi mümkün olduğunca keneye zarar vermeden gerçekleştirilmeli ve kene bir bütün olarak çıkartılmalıdır (Ergönül, 2008). Zira keneye zarar verilmesi durumunda keneler kusmaktadır ve kusmukları ile virüsleri insanlara bulaştırmaktadır. Bu nedenlerledir ki günümüzde, çıkartma işlemi sırasında kesinlikle kenenin ezilmemesi, kenelerin üzerlerine herhangi bir kimyasal madde dökülmemesi ve kenenin bir bütün şeklinde mekanik olarak çıkartılması kabul edilmektedir. Vücuttan çıkartılamayan olgularda, kene bütünlügünü bozmamak amacı ile eksizyonel biyopsi ile de kene çıkartma işleminin yapıldığı literatürde mevcuttur (Willen ve ark., 2007). Çalışmamızda olguların çoğunluğunda kenenin bir sağlık kuruluşunda çıkarıldığını, bunun- la birlikte hastanın kendisi veya bir yakını tarafindan da kenenin çıkarıldığını belirledik.

Vücudun görünen kısımlarında kenenin saptanması daha kolay iken görünmeyen kısımlarında ise bu tespit daha zor olabilir. Bu nedenle kene 1sirıkl bir hastada birden fazla bölgede kenenin bulunabileceği düşünülmeli ve hastalar tepeden tırnağa dikkatli bir şekilde değerlendirilmelidir. Ancak bu şekilde bir muayene ile hastanın vücudunun görünmeyen kısımlarındaki kene tespit edilebilir. (Edlow ve McGillicuddy, 2008) kenelerin vücutta sıklıkla saçlı deriye, kulak arkasına ve uyluğa yerleştiğini rapor etmişlerdir. Ülkemizde farklı coğrafik bölgede yaşayan ve kene 1sırması ile hastaneye başvuran hastaların değerlendirildiği çeşitli çalışmalarda, kenenin vücutta yerleştiği yerlerin sıklığ değişmektedir. (Taşkesen ve ark., 2008) kenelerin en s1k bacak (\%37) ve gövdeye (\%21) yerleştiğini, (Al ve ark., 2008) en sik baş-boyun ve bacaklara yerleştiğini, (Sümer ve ark., 2010) ise en çok bacaklara $(\% 34,52)$ ve gövdeye $(\% 11,9)$ yerleştiğini bildirmişlerdir. Biz çalışmamızda kenelerin en fazla gövdeye ve kollara yerleştiğini, daha az oranlarda da bacaklar, baş-boyun, genital bölge gibi yerlere yerleştiğini tespit ettik.

Kene 1sırıklı hastalarda, KKKA hastalı̆̆ gelişme riskini takip için tam kan sayımı ve karaciğer fonksiyon testleri (aspartataminotransferaz, alaninaminotransferaz, kreatin kinaz, alkalen fosfotaz, gamaglutamil transferaz, laktat dehidrogenaz ve bilirubin) belirlenmelidir (Çevik, 2004; Acar, 2006; Üstün ve Güven, 2009). Tam kan say1$\mathrm{m} 1$ ile hastada lökopeni ya da lokositoz, trombositopeni ve aneminin varlığı araştırılırken, karaciğer fonksiyon testleri ile karaciğerin etkilenip etkilenmediği araştırılmaktadır. Ayrıca KKKA hastalığ 1 gelişenlerde bariz bir kanama olmaksızın hemoglobin düzeyinin düşebileceği ve anemi görülebileceği de bildirilmiştir (Yalçın, 2003).

Swanepoel ve ark., (1989) yaptıkları bir çalışmada KKKA hastalığı düşünülen ve takipleri esnasında ölen ya da yaşayan hastaların laboratuvar bulgularını incelemişlerdir. Bu çalışmada ölen hastalarda başlangıçta total lökosit sayısının normal referans aralığında veya hafif yüksek olduğunu ve birinci haftanın sonuna doğru lökopeni geliştiğini, buna karşın yaşayan hastalarda ise tam tersine başlangıçta lökopeni bulunduğunu ve birinci haftanın sonuna doğru lökosit sayısının normale geldiğini bildirmişlerdir. Aynı zamanda ölen hastalarda trombositopeninin KKKA hastalığı için karakteristik bir bulgu olduğunu ve klinik tablonun ağır seyrettiği hastalarda hemoglobinde de düşmenin görüleceğini bildirmişlerdir. KKKA hastalarının klinik özelliklerinin tanımlandığı başka bir çalışmada ise başvuru sırasında hastaların \%69,5'inde trombositopeni, $\% 82,6$ 'sında lökopeninin bulunduğu ve \%17,3 oranında ölüm görüldüğü rapor edilmiştir (Çevik, 2004). Çalışmamızda hastaların başvuru sırasındaki lökosit sayısı 535$19000 \mathrm{bin} / \mathrm{uL}$ arasında, trombosit sayıs1 14100-557000 bin/uL arasinda ve hemoglobin 5,20-19 gram/dL arasinda değişmekteydi. Hastalarımızın \%29,2'sinde trombositopeni, \%8,3'ünde lökopeni, \%6,8'inde lökositoz ve $\% 29,2$ 'inde anemi mevcuttu. 
Taşkesen ve ark., (2008) kene 1sırıklı olgularda laboratuar incelemesinde tam kan sayımında lökopeni, trombositopeni ve aneminin bulunup bulunmadığının araştırılmasını ve ayrica AST, ALT, ALP, CPK, total bilirubin, LDH, Protrombin zamanı (PT), aktive parsiyel protrombin zamanı (aPTT) düzeylerinin de belirlenmesini gerektiğini belirtmişlerdir. Güngör ve ark., (2006) KKKA hastal1ğ1 tanısı almış dokuz çocuk hastanın tam kan sayımını ve biyokimya parametrelerini incelediklerinde hastalarının beşinde anemi ve lökopeninin, yedisinde ise trombositopeninin bulunduğunu, dördünde PT'de uzama, altısında CPK'da yükseklik, yedisinde AST ve ALT yüksekliği ve sekizinde de LDH yüksekliğinin bulunduğunu bildirmişlerdir. Hastalarımızın laboratuvar incelemelerinde AST düzeyi 10-2546 arasında ALT düzeyi 7-1883 arasında ve INR düzeyi 0,79-1,64 arasında idi. Hastalarımızın acil servise ilk başvurusu sırasında yapılan fizik muayenesi ve istenilen laboratuar testleri sonucunda 30 hastada $(\% 11,5)$ KKKA hastalığı ön tanısı ile ilgili servise yatırılmıştı. Yapilan testler sonucunda bu hastaların 8 tanesinde KKKA hastalığı tanısı doğrulanmıştı.

Sağlık Bakanlığ 1 verilerine göre son yıllarda hem
KKKA'lı vaka sayısı hem de buna bağlı ölüm artmıştır. Ülkemizde 2002-2009 yılları arasinda toplam 4453 KKKA vakasının tespit edildiği ve bu vakaların 218'inin öldüğü bildirilmiştir (T.C. Sağlık Bakanlığı, 2010). Bu sonuçlar kene 1sırıklarının ve buna bağlı gelişen KKKA hastalığ1nın ülkemiz için önemli bir sağlık sorunu olduğunu ortaya koymaktadır. Kesintisiz sağlık hizmeti veren acil servisler kene 1sırması sonucu başvuran hastalarla daha fazla karş1laşabilir. Bu nedenle özellikle başvuruların arttığ 1 dönemlerde, bu hastalar için acil servislerde uygun koşulların oluşturulması, sağlık personelinin eğitimi, halkın kenenin zararları ve korunma yolları hakkında bilgilendirilmesi gerekmektedir.

\section{Sonuc}

Kene 1sırması sonucu acil servise başvuran hastalar genellikle kırsal kesimde yaşamaktadır. Hastalar acil servise özellikle sıcak mevsimlerde başvurmaktadır. $\mathrm{Bu}$ şikâyetle başvuran hastalarda ayrıntılı fizik muayene yapılmalıdır. Acil servisler, kene 1sırması şikâyeti olan hastaların yönetiminde önemli bir yere sahiptir.

\section{KAYNAKLAR:}

Acar, A., 2006. Kırım Kongo Kanamalı Ateşi. TSK Kor. Hek. Bül. 5, 287-295.

Akyazı, R., Ecevit, O., 2006. Keneler ve Kırım Kongo Kanamalı Ateşi. OMÜ Zir. Fak. Derg.. 21, 340-349.

Al, B., Yıldırım, C., Söğüt, Ö., Yeşilkaya, A., 2008. Batman Devlet Hastanesi Acil Servisine Yedi Ayda Başvuran 39 Kene Isırı̆̆ının Değerlendirilmesi. A.A.T. D. 7, 40-43.

Arıkan, İ., Tıraş, Ü., Saraçoğlu, D., Taşar, M.A., 2009. Ege Tıp Derg.. 48, $29-31$.

Bozkurt, G.Y., Memikoğlu, K.O., Azap, A., Balık, İ., 2005. Kırım Kongo Kanamalı Ateşi: Olgu Sunumu. Ankara Üniversitesi Tıp Fakültesi Mecmuası. 58, 193-196.

Çevik, M.A., 2004. Kırım Kongo Hemorajik Ateşi: Klinik Özellikler. Klimik Derg. 7, 59-61.

Edlow, J.A., McGillicuddy, D.C., 2008. Tick paralysis. Infect. Dis. Clin. North Am. 22, 397-413.

Ergönül, Ö., 2008. Viral kanamalı ateşler. In: Willke TA, Söyletir G, Doğanay M, eds. İnfeksiyon Hastalıkları ve Mikrobiyolojisi. İstanbul: Nobel Tip Kitapevleri. 1251-1265.

Güngör, O., Eroğlu, Ö.K., Güven, A., Kalaycı, A.G., Duru, F., 2006. Çocuklarda Kırım Kongo Kanamalı Ateşi hastalığı. 50.Milli Pediatri Kongresi Özet Kitapçığı. 8-12 Kasım, Antalya. 281.

Kandiş, H., Katırc1, Y., Uzun, H., Güneş, H., Kara, İ.H., Geyik, F.M., 2010. Endemik Bir Bölgede Kene Isırı̆̆ı Nedeniyle Acil Servise Başvuran Olguların Demografik ve Epidemiyolojik Özellikleri. Düzce Tıp Derg.. 12, 18-23.

Kırdar, S., Ertuğrul, M.B., 2009. Kırım Kongo Kanamalı Ateşi. ADÜ Tıp Fakültesi Derg.. 10, 45-52.

Onguru, P., Akgul, E.O., Akinci, E., Yaman, H., Kurt, Y.G., Erbay, A., Bayazıt, F.N., Bodur, H., Erbil, K., Acıkel, C.H., Cevik, M.A., 2008. High serum levels of neopterin in patients with Crimean-Congo hemorrhagic fever and its relation with mortality. J. Infect. $56,366-370$.

Sümer, A., 2010. Kene Isırı̆̆ı Nedeniyle Kaş Devlet Hastanesi Acil Servisine Başvuran Hastaların Değerlendirilmesi. Kafkas Univ. Vet. Fak. Derg. 16, 49-53.

Swanepoel, R., Gill, D.E., Shepherd, A.J., Leman, P.A., Mynhardt, J.H., Harvey, S., 1989. The clinical pathology of CrimeanCongo hemorrhagic fever. Rev. Infect. Dis. 11, 794-800.

Taşkesen, M., Okur, N., Taş, M.A., 2008. Kene Isırması nedeniyle başvuran 19 olgunun değerlendirilmesi. Dicle Tıp Derg. 35, $110-13$.

T.C. Sağlık Bakanlı̆̆ı. Kırım Kongo Kanamalı Ateşi. http://www.saglik.gov.tr (erişim tarihi 10.04.2010)

Üstün, C., Güven, T., 2009. Kırım-Kongo Kanamalı Ateşi: Elazığ’da İlk Olgu. Klimik Derg.. 22, 31-3.

Willen, C., Mullen, G.R., Yee, J., Read, R.W., 2007. Conjunctival Attachment of a Tick: Clinicopathologic Report of a Case. J. Emerg. Med. doi:10.1016/j.jemermed.2007. 11.040

Yalçın, E., 2003. Hayvanlardan insanlara geçen hastalıklar: Kırım Kongo Kanamalı Ateşi. Erzurum Veteriner Kontrol ve Araştırma Enstitüsü Müdürlüğü Yayını. Erzurum.

Yilmaz, R.G., Buzgan, T., Irmak, H., Safran, A., Uzun, R., Cevik, M.A., Torunoglu, M.A., 2008. A preliminary report on CrimeanCongo haemorrhagic fever in Turkey, March - June 2008. Euro Surveill. 13, 18953. 